\title{
ACCEPTOR ACTIVITY, ISOACCEPTOR PROFILES AND FUNCTION IN PROTEIN SYNTHESIS OF TRANSFER RNAs FROM REGENERATING SKELETAL MUSCLE
}

\author{
GEORGE H. JONES \\ Department of Cellular and Molecular Bıology, Division of Biological Sciences, The University of Michigan, Ann Arbor, MI 48109 \\ (USA)
}

(Received May 5th, 1983)

Key words tRNA, Acceptor activity, Isoacceptor profile, Protein synthests, Muscle regeneration. (Rat skeletal muscle)

Transfer RNAs have been prepared from control and regenerating rat skeletal muscle. The yield of tRNA is highest during the early stages of the regeneration process $(5$ and 8 days following the induction of regeneration) and decreases to near control values thereafter. The amino acid acceptor activity (extent of aminoacylation) of tRNA from regenerating muscle was also found to be higher for some amino acids than the activity of control tRNA, and the maximum increase in activity was observed between 5 and 8 days following the initiation of regeneration with a decrease to control levels through 15 and 30 days. The isoacceptor pattern, determined by RPC-5 chromatography, for methionyl-tRNAs from control muscle and 5-day regenerating muscle were essentially indistinguishable, while a minor peak of prolyl-tRNA was observed in the population from 5-, 8- and 15-day regenerates which was apparently absent from the control tRNA. Lysyl-tRNAs from control muscle contain two major isoacceptors while a third isoacceptor is observed in the tRNA preparations from 5-, 8- and 15-day regenerating muscle. The relative amount of this third isoacceptor is highest in the 8-day population and decreases in amount in tRNAs from 15- and 30-day regenerates. Control muscle also contains two major glutamyl-tRNA species while a third isoacceptor can be detected in regenerates. The relative amount of this species increases during the early course of the regeneration process but is present at near control levels by $\mathbf{3 0}$ days following Marcaine injection. Cell-free protein synthesis using muscle polyribosomes showed that tRNAs from regenerating muscle were more effective in stimulating $\left.\right|^{35}$ S|methionine incorporation than tRNAs from control muscle.

Recent studies from this laboratory have dealt with the changes in protein synthesis which accompany the regeneration of skeletal muscle in rats. The model system used in these studies involves the direct injection into the muscle of the myotoxic drug, Marcaine (bupivacaine). It has been shown by Hall-Craggs [1], by Carlson and coworkers [2] and by others [3,4] that the injection of Marcaine into an appropriate muscle leads to a rapid and striking degeneration of that muscle which is followed by an equally dramatic regeneration phenomenon.

Changes in protein synthesis which occur be- tween 5 and 30 days following the injection of Marcaine have recently been characterized in the regenerating muscle system. In particular, it has been observed that there is an increased ability of muscle fragments to incorporate $\left[{ }^{35} S\right]$ methionine into protein during the early stages of regeneration and that the incorporation activity returns to near control values by the end of the regeneration process [5] and unpublished data. The increased activity of muscle fragments in protein synthesis seems to reflect, in part, an increase in both the yield and activities of polysomes from regenerating muscle as compared with controls. Again, the increases 
are maximal during the early stages of regeneration and polysome yield and activity levels return to near control values by 30 days following Marcaine injection. The regeneration process is also characterized by an increase in the yield of total RNA from regenerates as compared with controls. The larger yield of polysomes suggests that an increase in ribosomal RNA synthesis is at least partly responsible for the increase in the amount of total RNA obtained from regenerating muscle. This interpretation is also consistent with earlier observations of an increase in ribosome synthesis during the regeneration process [6] It has further been shown that the regeneration process occasions an increase in the amount of $\operatorname{Poly}(\mathrm{A})^{+}$RNA which is present in the regenerating muscle (unpublished data).

The data described above are thus compatıble with the notion that increases in ribosomal and messenger RNA levels are concomitants of the process of skeletal muscle regeneration. It seemed advisable, therefore, to determine whether the transfer RNA fraction was similarly affected by regeneration. Changes in tRNAs are known to accompany a number of developmental processes such as gland and organ development [7,8] tumorlgenesis $[9,10]$ and changes in cell division rate [11]. To determine how the regeneration process affects muscle tRNAs, the amıno acid acceptor actıvitıes. isoacceptor profiles and function in protein synthesis of tRNAs from control and regeneratıng rat skeletal muscle have been examined. Results of these experiments are presented below

\section{Materials and Methods}

Materials. Adult male Sprague-Dawley rats $(250-300 \mathrm{~g})$ were used in all experıments. The following amino acids utilized in the acceptance studies were obtained from New England Nuclear: $\left[{ }^{3} \mathrm{H}\right]$ leucine $(45.7 \mathrm{Cl} / \mathrm{mmol}),\left[{ }^{3} \mathrm{H}\right]$ glutamic acid $(49$ $\mathrm{C} 1 / \mathrm{mmol}),\left[{ }^{3} \mathrm{H}\right]$ alanine $(13.9 \mathrm{Cl} / \mathrm{mmol})\left[{ }^{3} \mathrm{H}\right] \mathrm{meth}-$ ionıne $(80 \mathrm{Ci} / \mathrm{mmol}),\left[{ }^{14} \mathrm{C}\right]$ proline $(290 \mathrm{mCi} / \mathrm{m}$ mol). $\left[{ }^{3} \mathrm{H}\right]$ Lysine $(75 \mathrm{Ci} / \mathrm{mmol}),\left[{ }^{3} \mathrm{H}\right]$ phenylalanıne $(17 \mathrm{Cl} / \mathrm{mmol}),\left[{ }^{3} \mathrm{H}\right]$ prolıne $(29 \mathrm{Ci} / \mathrm{mmol})$, $\left[{ }^{3} \mathrm{H}\right]$ serine $(3.4 \mathrm{Ci} / \mathrm{mmol}),\left[{ }^{3} \mathrm{H}\right]$ glycine $(12.3$ $\mathrm{Cl} / \mathrm{mmol}),\left[{ }^{3} \mathrm{H}\right]$ valine $(37 \mathrm{Cl} / \mathrm{mmol})\left[{ }^{14} \mathrm{C}\right]$ lysine (342 $\mathrm{mC} 1 / \mathrm{mmol}),\left[{ }^{14} \mathrm{C}\right]$ glutamic acid $(275 \mathrm{mCi} / \mathrm{m}$ mol) and $\left[{ }^{35} \mathrm{~S}\right]$ methionine $(1220 \mathrm{Cl} / \mathrm{mmol})$ were from Amersham. Adogen 464 for RPC-5 chromatography was generously donated by Dr. G. David Novell, Oak Ridge Natıonal Laboratory.

Marcaine injection procedure. Skeletal muscle regeneration was induced by the direct injection of $0.75 \%(\mathrm{w} / \mathrm{v})$ solutions of Marcaine in $0.9 \% \mathrm{NaCl}$ into the tibialis anterior of male rats as previously described [5]. Contralateral muscles were injected with saline only and served as controls. Muscles were excised for examination 5, 8, 15 and 30 days following incubation.

Isolation of subcellular components Transfer RNAs were isolated from control and regeneratıng muscle essentially as described previously [12]. A crude aminoacyl-tRNA synthetase preparation was obtained from rat liver as described [11]. Following DEAE-cellulose chromatography of the enzyme preparation it was dialyzed overnight agaınst two changes of Medium A [11] containing 25\% glycerol. Polyribosomes for cell-free protein synthesis were isolated from 5-day regenerating skeletal muscle exactly as described previously [5]

Conditions for aminoacylation and cell-free protein synthesis. Aminoacylation reaction mixtures were prepared essentially as described previously [13] except that ATP and magnesium concentrations were optimized for each of the amino acids tested in this study. All reaction mixtures contained $50 \mathrm{mM}$ Tris- $\mathrm{HCl}, \mathrm{pH} 7.6 / 5 \mathrm{mM} \mathrm{KCl} / 5$ $\mathrm{mM}$ 2-mercaptoethanol. Most amino acids were charged using final concentrations of $5 \mathrm{mM}$ ATP and $12 \mathrm{mM} \mathrm{MgCl}$. Amınoacyl-tRNA synthetases were present at concentrations of $1-3 \mathrm{mg} / \mathrm{ml}$ and radioactive amino acids at $1-200 \mu \mathrm{Cl} / \mathrm{ml}$ The lower amino acid concentrations were used for ${ }^{14} \mathrm{C}$-labelled amıno acids. Incubations were generally conducted for $15-30 \mathrm{~min}$ at $37^{\circ} \mathrm{C}$. and reaction mixtures were processed as described previously [13] Results expressed in Table II and Fig 1 reflect the extent of aminoacylation with the indicated amino acids following a $15 \mathrm{~min}$ incubation at $37^{\circ} \mathrm{C}$. Conditions for cell-free protein synthesis were as described previously [5] except that the rat liver-soluble enzyme fraction was passed through a DEAE-cellulose column before dialysis. In addition, polysomal reaction mixtures contained varyIng amounts of tRNA (1.5-15 $\mu \mathrm{g})$. Reaction volumes were $50 \mu 1$ and mixtures were processed as described previously [5]. 
Reverse phase chromatography. RPC-5 chromatography was carried out essentially as described $[9,14]$ using a $1.2 \times 45 \mathrm{~cm}$ or a $1.2 \times 95 \mathrm{~cm}$ column maintained at $27^{\circ} \mathrm{C}$. The columns were run at a flow rate of $42-48 \mathrm{ml} / \mathrm{h}$ and $1.5-3 \mathrm{ml}$ fractions were collected. tRNAs from control and regenerating muscle were differentially labelled with ${ }^{3} \mathrm{H}$ - or ${ }^{14} \mathrm{C}$-labelled amino acids to allow simultaneous separation on RPC-5 columns. Alıquots of appropriate fractions were precipitated with trichloroacetic acid and radioactivity was determıned by liquid scintillation counting.

\section{Results}

Yields of $t R N A$ from control and regenerating muscle

As indicated above, the regeneration process in skeletal muscle is accompanied by an increase in total and poly(A) ${ }^{+}$RNA. The data given in Table I also reveal that regenerating muscle contains higher levels of total tRNA than does control muscle. About 1.8-times more tRNA is obtained from regenerating muscle 8 days following Marcaine injection than can be isolated from control muscle. There is a decline in yield thereafter, such that by 30 days post-injection, the yield of tRNA is essentially identical to that of the control. It should be noted that maximum yields of total and $\operatorname{poly}(\mathrm{A})^{+}$RNA are also observed 8 days following the induction of the regeneration process (unpublished data).

Amino actd acceptor activity of $t R N A s$ from control and regenerating muscle

To determine whether the regeneration process

\section{TABLE I}

YIELDS OF tRNA FROM CONTROL AND REGENERATING SKELETAL MUSCLE

\begin{tabular}{lll}
\hline $\begin{array}{l}\text { Days post } \\
\text { injection }\end{array}$ & $\begin{array}{l}\text { tRNA yield } \\
\mu \mathrm{g} / \mathrm{g} \text { muscle }\end{array}$ \\
\cline { 2 - 3 } & Expt. 1 & Expt 2 \\
\hline Control & 208 & 272 \\
5 & 395 & 335 \\
8 & 448 & 412 \\
15 & 295 & 215 \\
39 & 206 & 254 \\
\hline
\end{tabular}

${ }^{a}$ Results of two separate experiments. affected the acceptor activity of muscle tRNAs, aminoacylation experiments were performed, using 10 of the 20 amino acids commonly found in proteins. Results of typical experiments are presented in Table II. In these experiments, the acceptor activity (extent of aminoacylation) of control tRNA and tRNA from 5-day regenerates was compared. It should be noted that the enzyme source in these experiments was rat liver, so that observed differences in acceptor activity must be due to differences in the tRNAs, not in the aminoacyl-tRNA synthetase population.

The data given in Table II show that for some of the amino acids tested there is little difference between the acceptor activity of control tRNA and tRNA from regenerating muscle. Thus, the acceptor actıvity of tRNA from 5-day regenerates for the amino acids leucine, phenylalanine, serine, glycine and methionine is within no more than $25-30 \%$ of control values. In contrast, the acceptor activity of tRNA from 5-day regenerates for the amıno acids lysine, glutamic acid, proline, valine and alanine was 1.5-3-times higher than the activity of control tRNA.

Fig. 1 shows the time course of the change in amino acid acceptor activity for four of the amino acids studied in Table II. It can be seen that in all cases there is an increase in acceptor activity be-

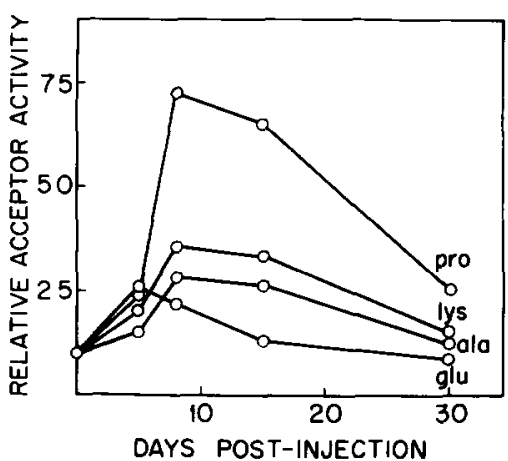

Fig. 1. Time course of the change in tRNA acceptor activity tRNAs were isolated from control muscle and from regenerating muscle 5, 8, 15 and 30 days following Marcaine injection Acceptor activity was measured as described in Materials and Methods for the amino acids alanine, glutamic acid, lysine and prolıne. Reaction mixtures contained about $15 \mu \mathrm{g}$ tRNA. Reaction mixtures were incubated for $15 \mathrm{~mm}$ and the data in the figure represent the extent of aminoacylation with the indicated amino acids 
TABLE II

\section{AMINO ACID ACCEPTOR ACTIVITY OF IRNAS FROM CONTROL AND REGENERATING SKELETAL MUSCLE.}

Results of two separate experıments Results are expressed as pmol/ $\mu \mathrm{g}$ of IRNA added to reaction mixtures For these experiments mixtures contained about $15 \mu \mathrm{g}$ tRNA. incubation was for $15 \mathrm{~min}$ and the data represent the extent of acylation with the indicated amino acids

\begin{tabular}{|c|c|c|c|c|}
\hline \multirow{3}{*}{$\begin{array}{l}\text { Amino } \\
\text { acid }\end{array}$} & \multicolumn{4}{|c|}{ tRNA source } \\
\hline & \multicolumn{2}{|c|}{ Control muscle } & \multicolumn{2}{|c|}{ 5-day regenerates } \\
\hline & Expt 1 & Expt 2 & Expt 1 & Expt 2 \\
\hline Lysine & 28 & 32 & 56 & 64 \\
\hline Leucıne & 89 & 99 & 126 & 108 \\
\hline Glutamıc acid & 18 & 10 & 43 & 47 \\
\hline Phenylalanıne & 50 & 36 & 49 & 59 \\
\hline Proline & 30 & 36 & 72 & 90 \\
\hline Serıne & 257 & 205 & 295 & 351 \\
\hline Glycine & 110 & 100 & 89 & 129 \\
\hline Valine & 131 & 75 & 189 & 195 \\
\hline Methionıne & 41 & 43 & 51 & 63 \\
\hline Alanıne & 35 & 25 & 44 & 48 \\
\hline
\end{tabular}

tween zero tıme and 8 days following Marcaine injection, and that the activity gradually decreases to near control values by 30 days following the induction of regeneration.

\section{$R P C-5$ chromatography of $t R N A s$}

To determine whether the increased acceptor activity of tRNA from regeneratıng muscle reflected changes in the isoacceptor patterns of tRNAs for those amino acids, the tRNAs were examıned by RPC-5 chromatography. In these experiments, tRNAs from control and regenerating muscle were labeled with either a $\left[{ }^{3} \mathrm{H}\right]$ - or $\left[{ }^{14} \mathrm{C}\right.$ ]amino (or ${ }^{35} \mathrm{~S}$ in the case of methionine) acid and were co-chromatographed on the reverse phase column. Three of the amino acids (proline, lysine and glutamic acid) for which large differences in acceptor activity were observed were studied in this series of experiments, and one amino acid (methıonine) for which activity differences were minor was included for comparison.

The RPC-5 profile for control and 5-day methionyl-tRNAs is shown in Fig. 2a. Although good separation of the methionine isoacceptors is observed there are no significant differences in the isoacceptor profiles for control tRNA and tRNA from 5-day regenerating muscle. Fig. $2 b$ shows the RPC-5 pattern for control and 5-day prolyl-
tRNAs. The control profile shows a single, broad peak while tRNA from 5-day regenerates displays a small shoulder (arrow) eluting slightly ahead of the major 1soacceptor. Fig. $2 b$ also shows the profile for prolyl-tRNAs from 8-day regenerates Again, a small peak eluting ahead of the major isoacceptor can be observed. The prolyl-tRNA pattern for 15-day regenerates is quite similar to that for 5-day regenerating muscle, and by 30 days the profile is essentially indistınguishable from the control (data not shown). These differences were observed in two separate tRNA preparations.

More strikıng differences were observed when lysyl-tRNAs from control and regeneratıng muscle were compared. Fig. 3a shows the isoacceptor profile for control tRNA and tRNA isolated 5-days post-injection. As has been observed by other researchers $[11,15]$, the lysyl-tRNA population consists of two major isoacceptors. These are the predominant species in the tRNA pools from control and regeneratıng muscle (Fig. 3). In addition. tRNAs from 5-, 8- and 15-day regenerates contain a third lysyl-tRNA species which elutes between the two major forms (F1g. 3, arrows). The relative amount of this third species seems to increase between 5 and 8 days and to decrease between 8 and 15 days post-injection (Fig. $3 \mathrm{~b}$ ) and the isoacceptor pattern for tRNA isolated from 30-day 

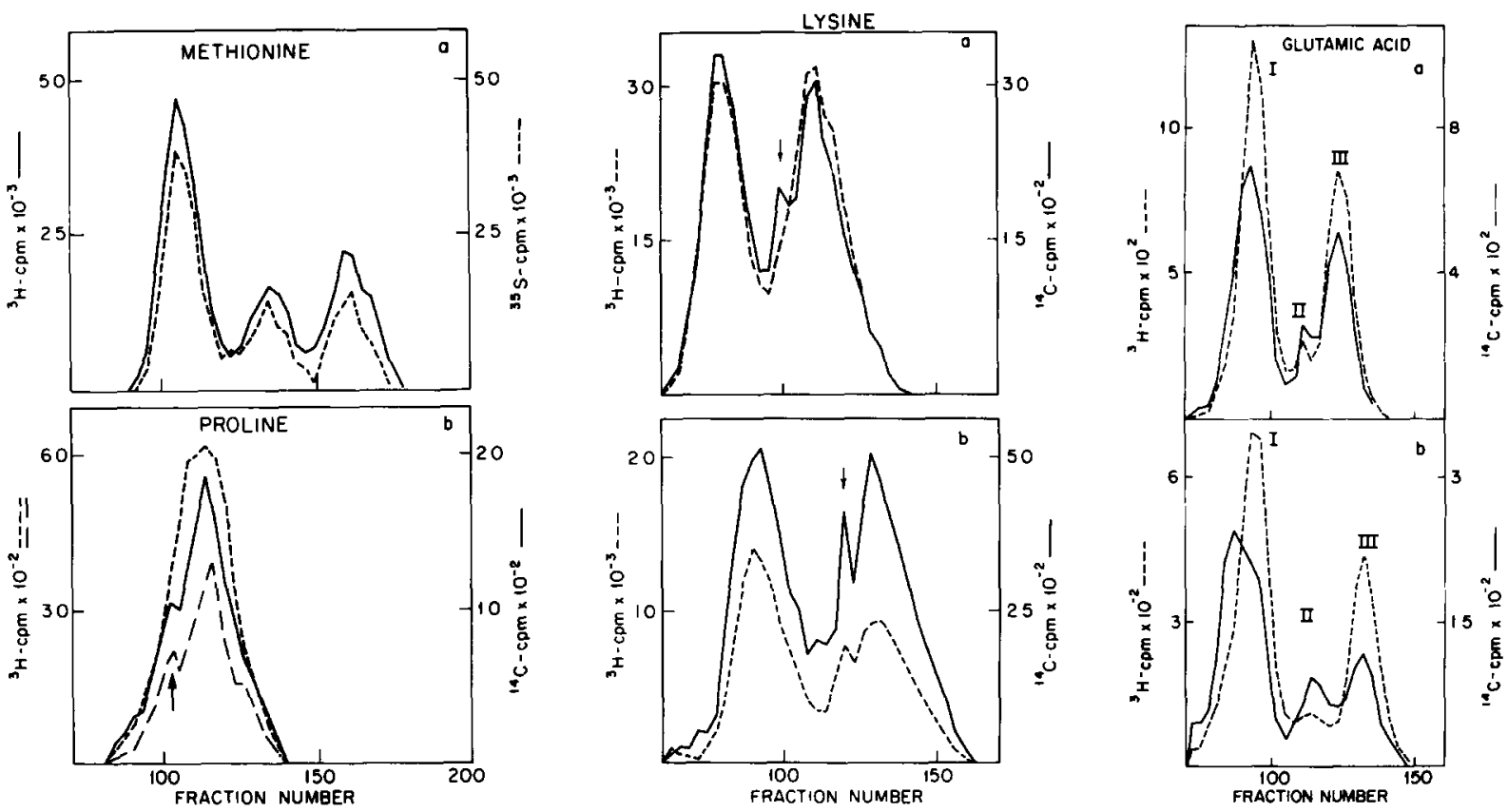

Fig. 2. RPC-5 profiles of methionyl-tRNAs (a) and prolyl-tRNAs (b) from control and regeneratıng skeletal muscle RPC-5 chromatography was performed as described in Materials and Methods using a $1.2 \times 45 \mathrm{~cm}$ column and a $\mathrm{NaCl}$ gradient of $050-070$ $M$ in $400 \mathrm{ml}$ for elution In (a), $71600{ }^{3} \mathrm{H}$-cpm and $127400{ }^{35} \mathrm{~S}$-cpm were applied to the column while in (b), $47800{ }^{3} \mathrm{H}$-cpm (control) and $17000{ }^{14} \mathrm{C}$-cpm (5 day) were applıed In a separate experıment, $29000{ }^{3} \mathrm{H}$-cpm of 8-day prolyl-tRNA were fractionated as described above $\longrightarrow$, 5-day; $\cdots . .$. , control, $-\cdot \cdot \cdot, 8$ day.

Fig 3 RPC-5 profiles of lysyl-tRNAs from control muscle and 5-day regeneratıng muscle (a) and from 8- and 15-day regeneratıng muscle (b). The $\mathrm{NaCl}$ gradient was $0.50-070 \mathrm{M}$ in $400 \mathrm{ml}$ and a $1.2 \times 45 \mathrm{~cm}$ column was used In (a), $183700{ }^{3} \mathrm{H}-\mathrm{cpm}$ and 17600 ${ }^{14} \mathrm{C}$-cpm were applied while in (b) $92200{ }^{3} \mathrm{H}$-cpm and $43500{ }^{14} \mathrm{C}$-cpm were applied to the column.

Fig 4. RPC-5 profiles of glutamyl-tRNAs from control muscle and 5-day regeneratıng muscle (a) and from 8- and 15-day regeneratıng muscle (b) A NaCl gradient of $0.50-075 \mathrm{M} \mathrm{NaCl}$ in $800 \mathrm{ml}$ was employed for elution from a $1.2 \times 95 \mathrm{~cm}$ column For the column run shown in (a), $28600{ }^{3} \mathrm{H}$ - and $18950{ }^{14} \mathrm{C}$-cpm were applied and in (b) $25800{ }^{3} \mathrm{H}$ - and $10600{ }^{14} \mathrm{C}$-cpm were applied

regenerating muscle is essentially indistinguishable from the control pattern shown in Fig. 3a (data not shown). The possible identification of this third isoacceptor as lysyl-tRNA 4 of Ortwerth and Liu [11] will be discussed below.

Significant differences in the isoacceptor profiles for the glutamyl-tRNAs were also observed in these experiments. As can be seen from Fig. 4, there are two major glutamyl isoacceptors in control and regenerating muscle. The relative amounts of these two isoacceptors appear to change over the course of the regeneration process and the relative amount of a third peak (peak II in Fig. 4) increases dramatically. The two major isoacceptors are present in a ratio of about 1.5:1 in control muscle and the minor species (peak II) makes up about $8 \%$ of the total glutamic acid acceptor activity (Table III). By 15 days following Marcaine injection the ratio of the two major isoacceptors (I and III) has increased from 1.5:1 to nearly $3: 1$ and peak II accounts for $18 \%$ of the total isoacceptor activity. By 30 days following the induction of regeneration, the relative amounts of the three isoacceptors have returned to near control values (Table III).

It should be noted that the isoacceptor profiles shown in Figs. 2-4 were not changed if the isotopes used to charge the different tRNAs were reversed, and that the patterns presented have been observed with at least two independently 


\section{TABLE III}

RELATIVE AMOUNTS OF GLUTAMYL-IRNAS I. II AND III IN CONTROL AND REGENERATING SKELETAL MUSCLE

The relative amount is expressed as percentage of the total area covered by the three soacceptor peaks

\begin{tabular}{llrl}
\multirow{2}{*}{$\begin{array}{l}\text { Days } \\
\text { post-injection }\end{array}$} & \multicolumn{2}{l}{ Relative amount } \\
\cline { 2 - 4 } & I & \multicolumn{1}{l}{ II } & III \\
\hline Control & 523 & 84 & 393 \\
5 & 538 & 129 & 333 \\
8 & 546 & 143 & 311 \\
15 & 604 & 182 & 214 \\
30 & 539 & 82 & 379 \\
\hline
\end{tabular}

Isolated $t R N A$ preparations for each regeneration tıme point.

\section{Function of muscle tRNAs in protein syinthesis}

While the literature is replete with reports of developmental changes in tRNA isoacceptor patterns, there are relatively few studies in which the relationship of these changes to tRNA function in protein synthesis has been examined. In order to determine whether the changes in acceptor activity and isoacceptor profiles reported above have functional significance, the ability of tRNAs from control and regenerating muscle to stımulate protein synthesis has been studied. In these experiments. polyribosomes were isolated from 5-day regenerates and varying amounts of tRNA were added to a polyribosomal cell-free protein synthesizıng system. Results of a typical experiment are shown in Fig. 5a. It can be seen that the addition of tRNA to the cell-free system caused a significant increase in the level of $\left[{ }^{35} \mathrm{~S}\right]$ methionine incorporated into protein. It is also apparent that tRNA from 8-day regenerates was more effective in stımulatıng protein synthesis at a given concentration than was tRNA from control muscle. Fig. 5b shows the 'specific activity' of the tRNA preparations used in this study, expressed as cpm $\left[{ }^{35}\right.$ S]methionine incorporated into protein by the cell-free system per $\mu \mathrm{g}$ of tRNA added, as determined from the linear portion of curves similar to those presented in Fig. 5a. Specific activities were determined at points corresponding to the addition of $1.5-2 \mu \mathrm{g}$

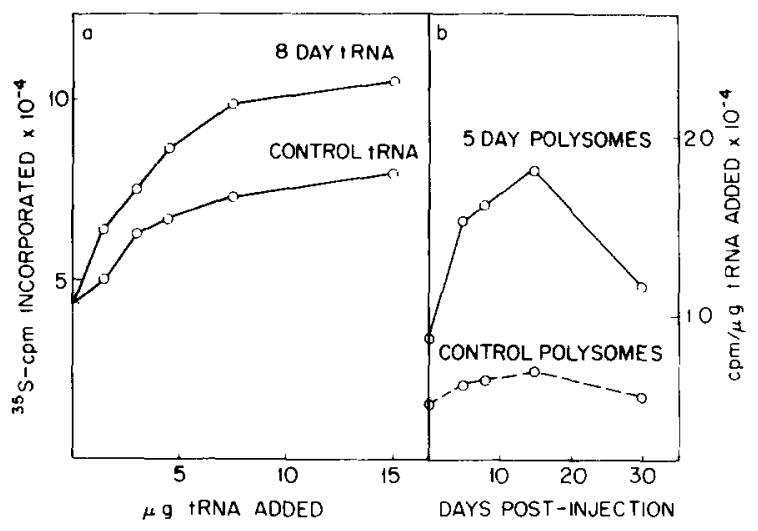

Fig 5 a Effects of increasing concentrations of tRNA from control and 5-day regeneratıng muscle on protein synthesis in a polysomal cell-free system Conditions for protein synthesis were as described in Materials and Methods and tRNA was added as indicated in the figure Polysomes were isolated from 5-day regenerates (b) Specific activity of IRNA from control and regeneratıng muscle in stımulating protein synthesis $R e$ sults are expressed as $\mathrm{cpm}\left[{ }^{35}\right.$ S]methionine incorporated into protein $/ \mu \mathrm{g}$ tRNA added to cell-free reaction mixtures Activities were determined from the linear portion of curves similar to those shown in (a), at points corresponding to the addition of 1 5-2 $\mu \mathrm{g}$ tRNA to reaction mixtures The solid line represents tRNA stimulation as measured using polysomes from 5-day regenerates and the dashed line represents simılar medsurements performed using control polysomes At each tıme point the raw incorporation data were corrected by subtracting the level of ${ }^{35} \mathrm{~S}$-methionine incorporation obtained in the absence of added IRNA The level of incorporation observed with control polysomes is lower than with 5 -day polysomes because of the decreased activity of the former preparation in protein synthesis (Jones. 1982)

of tRNA to polysomal reaction mixtures. The solid line in Fig. 5 represents the tRNA specific activity determined using polysomes from 5-day regeneratıng muscle, while the dashed line represents the specific actıvity as determined using polysomes from control muscle. It can be seen that there is an increase in the ability of tRNA from regenerates to stımulate protein synthesis early in the regeneration process, followed by a gradual decline in stimulatory specific activity to near control levels by 30 days following the induction of regeneration Further, it is apparent that the tRNAs were more effectıve in stimulating protein synthesis by polysomes from regenerating muscle than control polysomes. 


\section{Discussion}

The data presented in this report reveal a number of significant and reproducible changes which occur in the transfer RNA population of regeneratıng skeletal muscle over the time course of the regeneration process: (1) The yield of tRNA is higher from regenerating muscle than from controls. (2) There is an increase, for some amino acids, in the acceptor activity of tRNAs from regeneratıng muscle as compared with controls. (3) Striking differences in isoacceptor profiles for the amino acids lysine and glutamic acid are observed when tRNAs from control and regenerating muscle are compared. In particular, the RPC-5 column profiles reveal the presence of a new lysyl-tRNA during regeneration and a change in the relative amounts of the three glutamyl-tRNAs which are present in control muscle. (4) tRNA from regeneratıng muscle is more effective in stimulating the incorporation by muscle polysomes of $\left[{ }^{35} \mathrm{~S}\right] \mathrm{meth}$ ionine into protein than is control tRNA.

While the molecular mechamisms responsıble for the changes just described are not known, it is tempting to speculate that they represent the adaptation of the muscle translational apparatus to meet specific demands for increased protein synthesis during the regeneration process. In this regard, it has been observed by others that differences in the TRNA population of different mammalian tissues may reflect different developmental schedules for protein synthesis in those tissues. Ortwerth, for example, has found that the acceptor activity of lens tRNA for a number of amino acids is significantly different from the activity of muscle tRNA [7]. Ortwerth and coworkers have also demonstrated an increase in dividing cells in the amount of a specific lysyl-tRNA as compared to the levels of this isoacceptor in nondividing cells $[9,15]$. The elution position of the lysyl-tRNA which increases during skeletal muscle regeneration is similar to that described by Ortwerth and others for the lysyl-tRNA whose abundance increases in rapidly dividing cells $[9,11,15]$. It has also been shown that one of two glycyl-tRNAs is preferentially used for fibroin synthesis in the silkworm [16] and that a specific glycyl-tRNA is preferentially used for collagen synthesis in chick embryos [17]. It seems reasona- ble, therefore, that the increased synthesis of contractle proteins which takes place in regenerating muscle might also require the participation of specific tRNA isoacceptors which are absent from or present in only small amounts in control muscle.

The results presented here also add to the data which have been obtained on the effects of regeneration and other developmental processes, such as aging, on the mammalian translational apparatus. For example, Tidwell et al. [18] and Cajone et al. [19] have shown that regeneration of liver is accompanied by changes in the aminoacyl-tRNA synthetase population. In contrast to the results presented above for muscle, however, no differences in isoacceptor profiles were observed when tRNAs from normal and regenerating rat liver were compared [18,19]. Manjula and Sundari [22] and Mays et al. [23] have described age-related changes in the y1eld and amino acid acceptor activities of tRNAs from old rats as compared with young. While the regeneration studies described in the present report were performed using a different mammalian model, it is possible that the molecular mechanisms responsible for the alterations observed are simular to those which evoke like changes in regenerating and aging rat liver.

\section{Acknowledgments}

This research project was supported by grant number PCM-7904260 from the National Science Foundation and grant NS-17017 from the USPHS, Natıonal Institute of Neurology and Communicative Disorders and stroke.

\section{References}

1 Hall-Craggs, E.C.B. (1974) Exptl. Neurol. 43, 349-358

2 Carlson, B.M and Gutmann, E (1975) Pflugers Arch 353, 227-239

3 Benoit, P.W and Belt, W.D (1970) J Anat 107, 547-556

4 Jirmanova, I. and Thesleff, S (1972) Z. Zellforsch 131, $77-97$

5 Jones, G H. (1982) Muscle and Nerve 5, 281-290

6 Larson, P.F., Hudgson, P and Walton, J N. (1969) Nature $222,1168-1169$

7 Ortwerth, B.J. (1971) B1ochemıstry 10, 4190-4197

8 Chavancy, G, Chevallier, A., Fournier. A and Garel, J.-P. (1979) B1ochımie 61, 71-78

9 Bridges, K.R and Jones, G.H. (1973) Biochemıstry 12, 1208-1212 
10 Volkers, S.A S and Taylor, M W (1971) Biochemistry 10. 488-497

11 Ortwerth, B J and Liu. L. P (1973) Biochemistry 12 , 3978-3991

12 Johnson, M E and Jones. G H (1978) Biochem Pharmacol $27,1753-1757$

13 Jones, G H (1979) Biochemıstry 18, 4542-4547

14 Jones, G H (1974) Biochemistry 13, 855-860

15 Kleıman. L, Woodward-Jack, J . Cedergren, R J and Dion, R (1978) Nucleic Acids Res 5. 851-859

16 Chen, G S and Siddiqui, A Q (1974) Arch Biochem Biophys $161,109-117$
17 Carpousis. A, Christner, P and Rosenbloom. J (1977) J Biol Chem 252, 8023-8026

18 Tıdwell, T, Bruce. B J and Grıfın. A C (1972) Cancer res 32, $1002-1008$

19 Cajone, F, Ferrero. E and Bernellt-Zazzera, A (1980) Int J Biochem 11, 341-346

20 Agarwal, M K, Hanoune. J and Weinstern, I B (1970) Biochım Biophys Acta 224. 259-262

21 Manjula and Sundarı, R M (1980) J Bıoscı 3, 243-251

22 Mays, L L, Lawrence, A E, Ho, RW and Ackley, S (1979) Fed Proc 38. 1984-1988 